\title{
Feasibility study of the insulation of the enclosing walls of high-rise buildings
}

\author{
Olga Gamayunova ${ }^{1 *}$, Mikhail Petrichenko ${ }^{1}$, Tatyana Musorina $^{1}$, Eliza Gumerova ${ }^{1}$ \\ ${ }^{1}$ Peter the Great St. Petersburg Polytechnic University, 29 Politechnicheskaya St., St. Petersburg, \\ 195251, Russia
}

\begin{abstract}
On the example of a typical residential multi-apartment building, a feasibility study was carried out on the choice of energy-saving measures for the thermal insulation of facades. The decision to increase the energy efficiency of the building was made on the basis of calculating the loss of thermal energy through the external walls. Based on the parameters of the heating period, capital costs for additional thermal insulation of facades and calculated values of operating costs for heating, the optimum thickness of the additional layer of insulation is determined, in which the payback period assumes a minimum value.
\end{abstract}

\section{Introduction}

Reduction of energy costs is the most prospective area of resource saving in design and operation of buildings. Previous technical solutions to decrease the construction cost led to increase in cost of electricity [1].

In recent years, energy saving has become essential for new buildings and houses built several decades ago, when the issue of heat consumption was not considered.

Nowadays the state program about repair of old buildings is being implemented. It is necessary that it correlates with the energy saving program [2, 4-7]. At the same time, the economic component of investment projects should not be ignored. Energy-saving measures should reduce the amount of consumed energy and ought to be recoupable.

\section{Methods}

\subsection{Thermotechnical calculations of enclosing structures}

Let's make the analysis of choice of energy-saving measures for insulation of facades. The building is 9 -storey building located in Saint-Petersburg. The total area of external enclosing structures is equalled to 5963.1 sq.m. The climatic conditions for residential buildings are presented in table1.

Table 1. Climatic conditions for residential buildings located in Saint-Petersburg [3].

\begin{tabular}{|c|c|c|c|c|}
\hline No. & Indicator & $\begin{array}{c}\text { Parameter } \\
\text { label }\end{array}$ & $\begin{array}{c}\text { Standard } \\
\text { unit }\end{array}$ & $\begin{array}{c}\text { Calculated } \\
\text { value }\end{array}$ \\
\hline 1 & Calculated indoor temperature & $\mathrm{t}_{\mathrm{int}}$ & ${ }^{\circ} \mathrm{C}$ & 20 \\
\hline 2 & Calculated outdoor temperature & $\mathrm{t}_{\mathrm{ext}}$ & ${ }^{\circ} \mathrm{C}$ & -26 \\
\hline 3 & Duration of the heating period & $\mathrm{Z}_{\mathrm{ht}}$ & days & 220 \\
\hline
\end{tabular}

\footnotetext{
* Corresponding author: gamayunova@inbox.ru
} 


\begin{tabular}{|c|c|c|c|c|}
\hline 4 & Heating season degree-day & $\mathrm{D}_{\mathrm{d}}$ & ${ }^{\circ} \mathrm{C} \cdot$ days & 49 \\
\hline 5 & $\begin{array}{c}\text { Average outdoor temperature } \\
\text { during the heating period }\end{array}$ & $\mathrm{t}_{\mathrm{ht}}$ & ${ }^{\circ} \mathrm{C}$ & -1.8 \\
\hline
\end{tabular}

The outer walls are multilayer and are made of concrete, brick, plaster and lime-sand mortar.

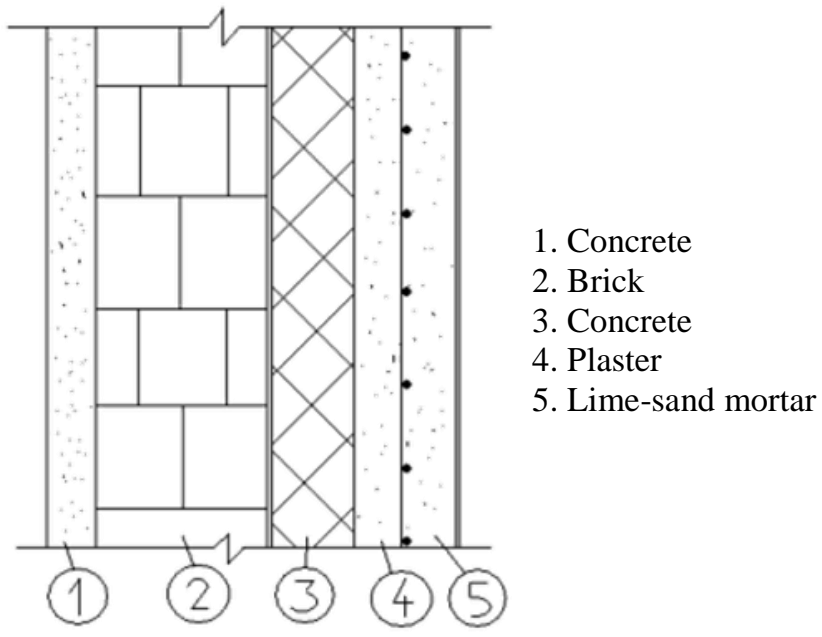

Figure 1. The structure of outer wall in residential apartment building

Thermotechnical characteristics of materials of outer wall are shown in table 2.

Table 2. Thermotechnical characteristics of materials of outer wall.

\begin{tabular}{|c|c|c|c|c|}
\hline No. & Material & $\begin{array}{c}\text { Thickness of } \\
\text { layer }(\delta), \mathrm{m}\end{array}$ & $\begin{array}{c}\text { Density }(\rho), \\
\mathrm{kg} / \mathrm{m}^{3}\end{array}$ & $\begin{array}{c}\text { Heat } \\
\text { conductivity } \\
(\lambda), \mathrm{W} /\left(\mathrm{m}^{* \circ} \mathrm{C}\right)\end{array}$ \\
\hline 1 & Concrete & 0.02 & 2300 & 1.2 \\
\hline 2 & Brick & 0.51 & 2100 & 0.72 \\
\hline 3 & Concrete & 0.08 & 2300 & 1.2 \\
\hline 4 & Plaster & 0.01 & 1800 & 0.93 \\
\hline 5 & $\begin{array}{c}\text { Lime-sand } \\
\text { mortar }\end{array}$ & 0.01 & 1500 & 0.78 \\
\hline
\end{tabular}

Thermal resistance of the wall (1):

$$
R_{0}=\left(R_{\text {int }}+R_{\text {ext }}+\sum R_{i}\right)=\frac{1}{23}+\frac{1}{8.7}+\left(\frac{0.02}{1.2}+\frac{0.51}{0.72}+\frac{0.08}{1.2}+\frac{0.01}{0.93}+\frac{0.01}{0.78}\right)=0.97 \frac{m^{2} *{ }^{\circ} \mathrm{C}}{W}
$$

Thermotechnical calculation showed that thermal resistance of wall $\mathrm{R}_{0}=0.97 \mathrm{~m}^{2} \times{ }^{\circ} \mathrm{C} / \mathrm{W}$ is lower than the required value $R_{\text {req }}=3.08 \mathrm{~m}^{2 * \circ} \mathrm{C} / \mathrm{W}$.

Due to identified discrepancy, it is necessary to insulate outer walls of construction object.

Minimal value of allowable thermal resistance of the thermal insulation material:

$$
R_{\text {ins }}^{r e q}=R_{\text {req }}-\left(R_{\text {int }}+R_{\text {ext }}+\sum R_{i}\right)=3.08-0.97=2.11 \frac{\mathrm{m}^{2} *^{\circ} \mathrm{C}}{W}
$$

Nowadays there are many options for insulation. We will determine the required thickness of wall with ISOVER Warm walls insulation to provide the required thermal resistance of wall: 


$$
\delta_{\text {ins }}^{r e q}=\lambda_{\text {ins }} * R_{\text {ins }}^{r e q}=0.036 * 2.11=76 \mathrm{~mm}
$$

Insulation ISOVER Warm walls is available in the form of plates with a thickness of 50 and $100 \mathrm{~mm}$. Let's consider that the thickness of the insulation will be equal to $100 \mathrm{~mm}$ :

$$
\begin{aligned}
R_{0}^{\text {ins }}=\left(R_{\text {int }}+R_{\text {ext }}\right. & \left.+\sum R_{i}\right)=\frac{1}{23}+\frac{1}{8.7}+\left(\frac{0.02}{1.2}+\frac{0.51}{0.72}+\frac{0.08}{1.2}+\frac{0.01}{0.93}+\frac{0.01}{0.78}\right)+\frac{0.1}{0.036} \\
& =3.75 \frac{\mathrm{m}^{2} *{ }^{\circ} \mathrm{C}}{W}
\end{aligned}
$$

According to the result, $\mathrm{R}_{0}=3.75 \mathrm{~m}^{2 * \circ} \mathrm{C} / \mathrm{W}>\mathrm{Rreq}_{0}=3.08 \mathrm{~m}^{2 * \circ} \mathrm{C} / \mathrm{W}$, the thickness of insulation is chosen right. The same calculations for other well-known insulations are given in table 3 .

Table 3. Technical assessment of insulation [8-13].

\begin{tabular}{|c|c|c|c|c|}
\hline Insulation & $\begin{array}{c}\text { Heat } \\
\text { conductivity } \\
\left(\lambda_{\text {ins }}\right), \frac{W}{m^{2} *^{\circ} \mathrm{C}}\end{array}$ & $\begin{array}{c}\text { Required } \\
\text { thickness of } \\
\text { insulation } \\
\left(\delta_{\text {ins }}^{\text {req }}\right)^{\dagger}, \mathrm{m}\end{array}$ & $\begin{array}{c}\text { Cost of 1 sq.m. } \\
\text { insulation } \\
\left(\mathrm{C}_{\text {ins }}\right), \mathrm{RUB}\end{array}$ & $\begin{array}{c}\text { Thermal } \\
\text { resistance of } \\
\text { insulated wall } \\
\left(R_{0}^{\text {ins }}\right), \frac{\mathrm{m}^{2} *^{\circ} \mathrm{C}}{W}\end{array}$ \\
\hline $\begin{array}{c}\text { ISOVER Warm } \\
\text { walls }\end{array}$ & 0.036 & $0.076(0.1)$ & 141 & 3.75 \\
\hline $\begin{array}{c}\text { ISOVER Warm } \\
\text { house }\end{array}$ & 0.038 & $0.080(0.1)$ & 135 & 3.60 \\
\hline $\begin{array}{c}\text { PAROC Extra } \\
\text { Smart }\end{array}$ & 0.036 & $0.076(0.1)$ & 222 & 3.75 \\
\hline $\begin{array}{c}\text { ROCKWOOL } \\
\text { Rockfacade }\end{array}$ & 0.037 & $0.078(0.1)$ & 590 & 3.67 \\
\hline URSA Terra & 0.036 & $0.076(0.1)$ & 127 & 3.35 \\
\hline $\begin{array}{c}\text { KNAUF Therm } \\
\text { Wall PRO }\end{array}$ & 0.042 & $0.089(0.1)$ & 274 & 3.60 \\
\hline $\begin{array}{c}\text { KNAUF Therm } \\
\text { Facade PRO }\end{array}$ & 0.038 & $0.080(0.1)$ & 370 & 3.75 \\
\hline
\end{tabular}

Insulation URSA Terra as the most low-cost insulation material which provides the biggest value of thermal resistance is chosen for insulation of facades (table 3 ).

\section{Results and Discussion}

\subsection{Return on investment in insulation of facades}

The equation (5) is used to calculate the discounted payback period of investments aimed at additional insulation of facades [14].

$$
T_{D}=\frac{\ln \left(1+\frac{\Delta \mathrm{K}}{\Delta \mathrm{E}} * \frac{r-i}{1+i}\right)}{\ln \left(\frac{1+r}{1+i}\right)}
$$

where $T_{D}$ - discounted payback period of investments in years;

\footnotetext{
$\dagger$ The required thickness of insulation is written in brackets.
} 
$\Delta \mathrm{K}$ - the difference between the capital costs for the construction of insulated and basic variants of the exterior walls (facades) of the building, RUB;

$\Delta \mathrm{E}$ - the difference between the loss of thermal energy through the outer walling before and after insulation, RUB;

$\mathrm{r}$ - average increase of electricity pricing in \%;

i - discount rate in $\%$.

The optimal option for additional insulation of facades will be considered the one for which the payback period will be minimal, i.e. the condition [15, 17-19]:

$$
T=f\left(\delta_{\text {ins }}\right) \rightarrow \min
$$

Capital costs for additional insulation of the outer wall is equaled to 1637 RUB / sq.m.:

127 RUB / sq.m. - cost of insulation URSA Terra $100 \mathrm{~mm}$ [16],

$110 \mathrm{RUB} /$ sq.m. - cost of fasteners;

280 RUB / sq.m.- cost of dry building mixtures;

1120 RUB / sq.m. - cost of full cycle of construction works.

We will accept that building company took out a loan for $13.7 \%$ for 3 years $(\mathrm{m}=36)$ for additional insulation. In this case, the annuity coefficient will be 0.034 :

$$
A=\frac{p_{\text {loan }} *\left(1+p_{\text {loan }}\right)^{m}}{\left(1+p_{\text {loan }}\right)^{m}-1}=\frac{0.011 *(1+0.011)^{36}}{(1+0.011)^{36}-1}=0.034
$$

where $\mathrm{m}$ - duration of credit payment in months;

$p_{\text {loan }}$ - monthly discount rate.

$$
p_{\text {loan }}=\frac{0.137}{12}=0.011
$$

Thus summed investments will be equaled to 2003.70 RUB per sq.m.:

$$
\Delta \mathrm{K}=36 * 0.034 * 1637=2003.70 \mathrm{RUB} / \text { sq. m. }
$$

The annual saving, which is achieved because of works on renovation of facades of the existing building, is defined by the formula:

$$
\Delta \mathrm{E}=\left(V_{1}-V_{2}\right) * \frac{0.024 * D_{d}}{1163} * c_{T}
$$

Heat conductivity of outer walls without additional insulation:

$$
V_{1}=\frac{1}{R_{0}^{1}}=\frac{1}{0.97}=1.03 \frac{W}{m^{2} *{ }^{\circ} \mathrm{C}}
$$

The required thermal resistance for the exterior walls of residential buildings due to the climatic conditions of Saint-Petersburg is equal to $\mathrm{R}_{\text {req }}=3.08 \mathrm{~m}^{2 * \circ} \mathrm{C} / \mathrm{W}$, which corresponds to the heat conductivity $\mathrm{V}_{2}$ :

$$
V_{2}=\frac{1}{R_{0}^{r e q}}=\frac{1}{3.08}=0.325 \frac{W}{m^{2} *^{\circ} \mathrm{C}}
$$

Considering the fact, that electricity cost $c_{T}$ is equaled to $1678.72 \mathrm{RUB} / \mathrm{Gcal}$, the value of decrease of operation costs for the first heating period including results of energy-saving measures is $117.13 \mathrm{RUB} / \mathrm{m}^{2}$.

$$
\begin{aligned}
\Delta \mathrm{E}=\left(V_{1}-V_{2}\right) * \frac{0.024 * D_{d}}{1163} * c_{T}=(1.03-0.325) * \frac{0.024 * 4796}{1163} * 1678.72 \\
=117.13 R U B / \text { sq. } m .
\end{aligned}
$$


Electricity pricing has been increasing at $11.3 \%$ per year for last 10 years (table 4 ). Thus, the average annual growth of pricing is equaled to 0.113 [20, 21].

Table 4. Dynamics of growth of electricity pricing in Saint-Petersburg for last 10 years.

\begin{tabular}{|c|c|c|}
\hline Year & $\begin{array}{c}\text { Electricity pricing, } \\
\text { RUB / Gcal }\end{array}$ & $\begin{array}{c}\text { Difference between } \\
\text { electricity pricing in last } \\
\text { and actual years }\end{array}$ \\
\hline 2008 & 650.00 & - \\
\hline 2009 & 795.73 & $+22.4 \%$ \\
\hline 2010 & 931.00 & $+17.0 \%$ \\
\hline 2011 & 1050.00 & $+12.8 \%$ \\
\hline 2013 & 1175.00 & $+11.9 \%$ \\
\hline 2014 & 1351.25 & $+15.0 \%$ \\
\hline 2015 & 1408.01 & $+4.2 \%$ \\
\hline 2016 & 1541.78 & $+9.5 \%$ \\
\hline 2017 & 1621.95 & $+5.2 \%$ \\
\hline 2018 & 1678.72 & $+3.5 \%$ \\
\hline
\end{tabular}

Discount rate of future cash flows is equaled to $7.5 \%$ [22].

Thus, the payback period of investment in the insulation of facades of the existing building will be equaled to 13.6 years:

$$
T_{D}=\frac{\ln \left(1+\frac{\Delta \mathrm{K}}{\Delta \mathrm{E}} * \frac{r-i}{1+i}\right)}{\ln \left(\frac{1+r}{1+i}\right)}=\frac{\ln \left(1+\frac{2003.7}{117.13} * \frac{0.113-0.075}{1+0.075}\right)}{\ln \left(\frac{1+0.113}{1+0.075}\right)}=13.6 \text { years }
$$

\section{Conclusion}

Energy-saving measures should be recoupable. Unfortunately, the problem of optimization of long-term investments in energy-saving measures in the construction and operation of buildings is rarely considered, especially using parametric models.

In this article, the decision to improve the energy efficiency of residential building was made based on the calculation of heat losses through the outer walls. The optimal insulation thickness is determined due to the parameters of the heating period, capital costs for additional insulation and calculated operating costs and allowed to minimize the payback period.

\section{References}

1. A.S. Gorshkov, N.I. Vatin, P.P. Rymkevich, O.O. Kydrevich. Mag. Civ. Eng., 2 (78), $65-$ $75(2018)$

2. S.V. Korniyenko, N.I. Vatin, A.S. Gorshkov. Mag. Civ. Eng., 4(64), 10-25 (2016)

3. A.S. Gorshkov, V.Ya. Olshevskij, R.A. Gorshkov, A.V. Kovredov. Construction of Unique Buildings and Structures, 4 (67), 32-51 (2018)

4. S.V. Kornienko, N.I. Vatin, A.S. Gorshkov. Construction of Unique Buildings and Structures, 12 (51), 45-60 (2016)

5. E.S. Ivanova, A.S. Gorshkov. Construction of Unique Buildings and Structures, 4 (43), 58-72 (2016)

6. D.N. Tseytin, N.I. Vatin, D.V. Nemova, P.P. Rymkevich, A.S. Gorshkov. Construction of Unique Buildings and Structures, 1 (40), 20-31 (2016) 
7. E. Gumerova, O. Gamayunova, R. Gorshkov. IOP Conference Series: Earth and Environmental Science 19, 012185 (2017)

8. O. Gamayunova, E. Gumerova, N. Miloradova. E3S Web of Conferences, 02046 (2018)

9. O. Gamayunova, T. Musorina, A.D. Ishkov. E3S Web of Conferences, 02045 (2018)

10. E. Gumerova, O. Gamayunova, L. Shilova. MATEC Web of Conferences, 06020 (2017)

11. A.S. Gorshkov, P.P. Rymkevich, D.V. Nemova. Energy efficiency, 2 (2014)

12. A.S. Gorshkov, P.P. Rymkevich, N.I. Vatin. Energy efficiency, 7 (2014)

13. A.S. Gorshkov. Energy efficiency, 4 (2014)

14. V.N. Bukhartsev, M.R. Petrichenko. Hydrotechnical construction, 4, 33-36 (2001)

15. M.R. Petrichenko. Examples of research, 31-35 (2016)

16. M. Petrichenko, N. Vatin, D. Nemova, N. Kharkov, A. Korsun. Applied Mechanics and Materials, 672-674, 1903-1908 (2014)

17. E.A. Statsenko, A.F. Ostrovaia, T.A. Musorina, M.I. Kukolev, M.R. Petritchenko. Mag. Civ. Eng., 8 (68), 86-91 (2016)

18. T.A. Musorina, O.S. Gamayunova, M.R. Petrichenko. Vestnik MGSU, 11 (110), 12691277.

19. M.R. Petrichenko, E.V. Kotov, D.V. Nemova, D.S. Tarasova, V.V. Sergeev. Mag. Civ. Eng., 1 (77), 130-140 (2018)

20. S.V. Korniyenko, N.I. Vatin, A.S. Gorshkov. Mag. Civ. Eng., 4 (64), 10-25 (2016)

21. Didenko, N.I., Skripnuk, D.F., Mirolyubova, O.V. IOP Conf. Ser. Earth Environ. Sci., 72 (1), (2017)

22. Lozhkin, V., Tarkhov, D., Timofeev, V., Lozhkina, O., Vasilyev, A. IOP Conf. Ser. Mater. Sci. Eng., 158 (1), (2016)

23. Rudenko, D., Skripnuk, D. Int. Multidisciplinary Sci. Geoconf. Surveying Geology Mining Ecology Manage., SGEM , 3, 209-216 (2016)

24. Petritchenko, M.R., Subbotina, S.A., Khairutdinova, F.F., Reich, E.V., Nemova, D.V., Olshevskiy, V.Ya., Sergeev, V.V. Mag. Civ. Eng., 73 (5), 40-48 (2017)

25. Skripnuk, D.F., Samylovskaya, E.A. IOP Conf. Ser. Earth Environ. Sci., 180 (1), (2018). 26. Musorina, T., Olshevskyi, V., Ostrovaia, A., Statsenko, E. MATEC Web Conf., 73, (2016)

27. Kitanina, E.E., Kitanin, E.L., Bondarenko, D.A., Kravtsov, P.A., Peganova, M.M., Stepanov, S.G., Zherebzov, V.L. J. Phys. Conf. Ser., 925 (1), (2017) 